\title{
Akıllı Telefon Bağımlılığının Çalışanların İş Tatminleri Üzerine Etkisi (The Effect of Smartphone Addiction on Employees' Job Satisfaction)
}

\section{Mahmut ÖZDEMİR iD a Nurcan ÇETINER iD $b$}

a Kırıkkale Üniversitesi, İktisadi ve İdari Bilimler Fakültesi, Kırıkkale, Türkiye. mahmudozdemir@hotmail.com

b Karamanoğlu Mehmetbey Üniversitesi, Kazım Karabekir Meslek Yüksekokulu, Karaman, Türkiye. nurcancetiner@kmu.edu.tr

\begin{tabular}{ll}
\hline MAKALE BİLGisi & ÖZET \\
\hline Anahtar Kelimeler: & Amaç - Teknoloji ile iletişim araçlarında yaşanan değişimler insan yaşamında birçok kolaylı̆̆ı \\
İş Tatmini & beraberinde getirmekte olup, bu gelişmeler iletişim araci olarak kullandığımız telefon teknolojisinde de \\
Akıllı Telefon Bağımlılığı & ilerlemelere yardımcı olmuştur. Bu araştırmada çalışanların, akıllı telefon bağımlılık düzeylerinin, iş \\
Teknoloji Bağımlılığı & tatminleri üzerine etkisi incelenmiş olup, çalışanların demografik özelliklerine göre akıllı telefon \\
& bağımlılık düzeylerinin ve iş tatmin düzeylerinin değişiklik gösterip göstermediği incelenmiştir.
\end{tabular}

Gönderilme Tarihi 10 Mart 2021

Revizyon Tarihi 16 Haziran 2021

Kabul Tarihi 20 Haziran 2021

Makale Kategorisi: Araştırma Makalesi
Yöntem - Görgül bir çalışma olan araştırmada ilişkisel tarama modeli kullanılmıştır. Araştırma verileri kolayda örnekleme yöntemiyle ulaşılabilen Türkiye'de özel sektör ve kamu sektöründe faaliyet gösteren kurumlarda çalışan, 18 yaş üstü 483 çalışandan elde edilmiştir. Veri toplama aracı olarak Google form aracılığıyla oluşturulan demografik bilgi formu, iş tatmini ölçeği ve akıllı telefon bağımlılığı ölçeğinden oluşan anket kullanılmıştır. Veriler üzerinde normallik analizi, geçerlilik ve güvenirlik testleri, keşfedici faktör analizi, betimleyici istatistikler, korelasyon ve regresyon analizleri gerçekleştirilmiştir.

Bulgular - Analiz sonucunda çalışanların akıllı telefon bağımlılık düzeyleri ile iş tatmin düzeyleri arasında ilişkinin anlamlı, orta düzeyde ve olumlu olduğu, yüksek düzeyde akıllı telefon bağımlılık düzeyine sahip katılımcıların iş tatmin düzeylerinin yüksek olduğu, çalışanların demografik özelliklerinin her iki değişken üzerinde de etkili olmadığı sonucuna ulaşılmıştır.

Tartışma - Gelecekteki çalışmalar ile örnek genişletilerek ve farklı sektörlerde konunun incelenmesi, analiz sonucu elde edilen verilerin genellenebilmesi ve literatüre katkıda bulunması açısından fayda sağlayabilecektir.

\begin{tabular}{|c|c|}
\hline ARTICLE INFO & ABSTRACT \\
\hline $\begin{array}{l}\text { Keywords: } \\
\text { Job Satisfaction } \\
\text { Smartphone Addiction } \\
\text { Technology Addiction }\end{array}$ & $\begin{array}{l}\text { Purpose - Changes in technology and communication tools bring many conveniences in human life, and } \\
\text { these developments have helped advances in the telephone technology that we use as a communication } \\
\text { tool. In this study, the effect of employees' smartphone addiction levels on their job satisfaction was } \\
\text { examined and whether their smartphone addiction levels and job satisfaction levels differ according to } \\
\text { the demographic characteristics of the employees. }\end{array}$ \\
\hline $\begin{array}{l}\text { Received } 10 \text { March } 2021 \\
\text { Revised } 16 \text { June } 2021 \\
\text { Accepted } 20 \text { June } 2021\end{array}$ & $\begin{array}{l}\text { Design/methodology/approach - The relational scanning method was used in the research, which is an } \\
\text { empirical study. Research data were obtained from } 483 \text { employees over the age of } 18 \text { workings in } \\
\text { institutions operating in the private and public sectors in Turkey, which can be easily accessed by } \\
\text { sampling method. As a data collection tool, a questionnaire consisting of demographic information } \\
\text { form, job satisfaction scale, and smartphone addiction scale was used. Normality analysis, validity and } \\
\text { reliability tests, exploratory factor analysis, descriptive statistics, correlation, and regression analyzes } \\
\text { were performed on the data. }\end{array}$ \\
\hline \multirow{2}{*}{$\begin{array}{l}\text { Article Classification: } \\
\text { Research Article }\end{array}$} & $\begin{array}{l}\text { Findings -As a result of the analysis, it was concluded that the relationship between the smartphone } \\
\text { addiction levels of the employees and their job satisfaction levels was significant, moderate, and } \\
\text { positive, participants with the high level of smartphone addiction had high job satisfaction levels, and } \\
\text { the demographic characteristics of the employees were not effective on both variables. }\end{array}$ \\
\hline & $\begin{array}{l}\text { Discussion - By expanding the example with future studies and examining the subject in different } \\
\text { sectors, it will be beneficial in terms of generalizing the data obtained as a result of the analysis and } \\
\text { contributing to the literature. }\end{array}$ \\
\hline
\end{tabular}




\section{Giriş}

Gelişen teknoloji ile birlikte iletişim araçlarında yaşanan değişimler insan yaşamında birçok kolaylığ1 beraberinde getirmektedir. Teknolojide yaşanan bu gelişmeler iletişim aracı olarak kullandığımız telefon teknolojisinde de ilerlemelere yardımcı olmuş ve telefonu sadece iletişim aracı olma özelliğinden çıkarmış, dünyayı avuç içine almamıza yardımcı olan, bireylerin istedikleri yer ve zamanda internete girme, elektronik postalarını kontrol etmelerine imkân tanıyan, video, resim, doküman paylaşmalarına yardımcı olan adeta minik bilgisayarlara dönüştürmüştür. Yaşanan bu değişimle beraber bireylerin gerek iletişim gerek sosyalleşme ihtiyaçlarına cevap veren akıllı telefonlar, onların hayatlarının ayrılmaz bir parçası haline gelmiş bulunmaktadır.

We Are Social'ın Ekim 2020 raporuna göre dünyada akıllı telefon kullanıcılarının sayısı dünya nüfusunun $\% 67$ 'si oranında olan 5 milyar 200 milyon kişiye ulaşmış durumda olup, Türkiye'de akıllı telefon kullanım oranı $\% 89^{\prime}$ dur ve Türkiye'de akıllı telefon aracılığıyla günlük ortalama internet kullanım süresi 4 saat 46 dakikadır (Kemp, 2020: 7). TÜIKK Ağustos 2020 raporuna göre ise Türkiye'de internet kullanan bireylerin oranının 2019 yılında \%75,3 iken 2020 yılında \%79 olduğu, evden internete erişim imkânının 2019 yılında $\% 88,3$ iken 2020 yılında \%90,7 olduğu, internet erişiminde hanelerin \%50,8'i sabit genişbant (ADSL, kablolu internet, fiber vb.) ile internete erişim sağlarken, $\% 86,9^{\prime}$ u mobil genişbant bağlantı ile internete erişim sağladığı gözlemlenmektedir.

Bilgi teknolojilerinde ve internette yaşanan gelişmelere paralel olarak internet teknolojileri, bireylerin gerek iş hayatı gerek özel hayatlarının her aşamasında etkisini gösteren vazgeçilmez bir parçası haline gelmiş durumdadır. Mobil cihazlar aracılığı ile sosyal ağlara erişimin kolaylaşması, bireylerin bilgiye daha kolay erişim sağlamalarına olanak tanımıştır (Çetinkaya ve Şahbaz, 2019: 386; Çetinkaya ve Şahbaz, 2020: 153). Özellikle örgütler bilgi teknolojilerindeki gelişmeleri takip ederek, gelişmelere ayak uydurabilmek amaciyla söz konusu teknolojileri örgüt bünyelerine dâhil etmeye, işleri geleneksel olmayan yöntemlerle idame ettirebilme, çalışan performansını olumlu yönde etkileme ve performansı artırma aracı olarak internetin sunmuş olduğu fırsatları kullanmaya başlamışlardır (Lim, 2002: 675).

Diğer taraftan bireylerin teknolojik araçları kullanımında kontrolünün kaybolması ve bu araçları sınırsız kullanmaları nedeniyle faydalarının yanı sıra çok ciddi zararlara da neden olabilmektedir. Diğer bağımlılıklar gibi teknoloji bağımlılı̆̆ı da kişiye, ailesine, topluma psikolojik, sosyal ve ekonomik açıdan zarar verebilmektedir. Teknoloji bağımlılıklarından biri olan akıllı telefon bağımlılığı da insanların son zamanlarda karşı karşıya kaldıkları psikolojik bir rahatsızlık durumudur. Örgütler belirlenen hedeflere ulaşmada emek girdisi olan insan kaynağının önemli olduğunu (Çetiner ve Atar, 2021: 175), gelişen teknolojik değişimlere ayak uydurabilmenin yanı sıra söz konusu teknolojileri kullanarak örgütsel hedeflere ulaşmaya çalışan personelinin bu konuda daha verimli olabilmesi için işinden tatmin olması gerekliliğinin de farkına varmış durumdadirlar.

Genel olarak çalışanların işlerine yönelik takınmış oldukları genel tutum olarak ifade edebileceğimiz iş tatmini, yaşamlarının önemli bir bölümünü içeren ve hayatlarının büyük bir kısmını işte geçiren çalışanların üretkenlik, devamsızlık veya işten ayrılma gibi işle ilgili davranışları üzerindeki etkileri açısından önem arz etmektedir (Oshagbemi, 2000: 331). Bu yönü ile örgütsel davranış araştırmacılarının ilgisini çeken çalışanların iş tatminlerine etki eden durumlar da araştırmacıların dikkatlerini üzerinde toplayan konular içerisine dâhil olmaktadır.

Bu bağlamda, "teknolojide yaşanan gelişmelere paralel olarak kullanım alanları ve yoğunluğu her geçen gün değişen akıllı telefonların bağımlılık düzeyinde riskli oranda kullanımı çalışanların iş tatmin düzeylerine etki etmekte midir?" sorunsalından hareketle araştırmanın amacı; akıllı telefon bağımlılık düzeyinin çalışanların iş tatminleri üzerinde etkisi olup olmadı̆̆ını belirlemeye çalışmaktır.

\section{Kavramsal Çerçeve}

\subsection{Akıllı Telefon Bağımlılı̆̆ı}

TDK sözlüğe göre bağımlı olma hali olarak tanımlanan bağımlılık (TDK, 2020) günümüzde sadece uyuşturucu veya madde bağımlılığı anlamına gelmemekte, internet, oyunlar ve hatta akıllı telefonlar için de kullanılmaktadır (Kwon vd., 2013: 1). Psikiyatrik bir sendrom olan bağımlılığın teşhisi için; kullanılan 


\section{M. Özdemir - Nurcan Çetiner 13/2 (2021) 1679-1694}

maddeye tolerans gelişmesi, kullanımı bırakmak için gerçekleştirilen çabaların sonuçsuz kalması, madde kullanımı sonucu sosyal, mesleki ve kişisel etkinliklerin olumsuz etkilenmesi, fiziksel veya ruhsal sorunların baş göstermesi gibi ölçütlerin yalnızca üçünün bir arada bulunması yeterli olmaktadır (Yeşilay, 2020).Bireyin bağımlısı olduğu teknolojik ürüne ulaşamaması durumunda yaşadığı yoksunluk durumu olarak tanımlayabileceğimiz teknoloji bağımlılı̆̆ı, çok kısa süre diyerek saatlerce teknolojik araçları kullanmak, uzun süre bilgisayar kullanımına bağlı fiziksel sorunlar yaşamak, planlanan sürenin ötesinde teknolojik araçları kullanmak ve söz konusu teknolojik unsurların kullanımından kendini alıkoyamamak gibi belirtilerle kendini göstermektedir (Yeşilay, 2020a). Söz konusu bağımlılık fiziksel, ruhsal ve sosyal açıdan insan yaşamını olumsuz yönde etkilemektedir.

Teknolojik cihazlarda görülen gelişmeler sayesinde bilgisayar, tablet ve akıllı cep telefonlarının kullanım oranlarının artması ve yaygınlığı, çalışanların günlük alışkanlıklarında ve davranışlarında değişikliklere neden olmakta, bilgi alışverişini ve iletişimi kolaylaştırmakta, geleneksel coğrafi sınırları kaldırarakçok sayıda insanın mekâna bağlı olmadan kaynak ve bilgi paylaşımlarını kolaylaştırmakta, birden fazla işlemi aynı anda gerçekleştirmelerine imkân tanımaktadır (Bragazzi ve Puente, 2014: 156). Bilgi iletişim teknolojilerinde yaşanan gelişmelere paralel olarak internet ağının yaygınlaşması, akıllı telefonlardaki gelişimle birlikte internet erişiminin kolaylıkla sağlanabilmesi, akıllı telefon kullanımının insanların hayatları, özellikle de iş yaşamlarında olumlu etkisi, akıllı telefon kullanım oranlarında görülen artış, bireylerin akıllı telefon bağımlısı olmaları ile ilgili endişeleri giderek artırmaktadır.

Tıpkı internet bağımlığı gibi bir davranışsal bağımlılık türü olarak kabul edilen ve alan yazın incelendiğinde "Mobil Telefonunun Aşırı Kullanımı", "Sorunlu Mobil Telefon Kullanımı" şeklinde de ifade edilen akıllı telefon bağımlılığı; bir maddeyle ilişkisi olmamasına rağmen kullanılmadığı durumlarda bireyin rahatsızlık duymasına neden olan bir bağımlılık türüdür (Yıldırım vd., 2019: 27). Bireylerin akıllı telefon kullanımından zevk alması, akranları tarafından kabul görme isteği gibi sosyal öz-yeterlilik, aile baskısı nedeniyle yaşanılan stres, içinde bulunduğu ruh halini iyileştirme ve eğlence isteği, onları daha fazla akıllı telefon kullanıma teşvik etmekte ve akıllı telefon bağımlılık düzeylerini olumlu yönde etkilemektedir (Chen vd., 2017: 891; Chui, 2014: 49). Ayrıca bireylerin sahip oldukları kişilik özellikleri ve sosyal medya kullanım oranlarının da yaşadıkları akıllı telefon bağımlılık düzeylerine artırıcı etki ettiği görülmektedir (Işık ve Kaptangil, 2018: 695).

Akıllı telefon bağımlılı̆̆ı gösteren bireyler üzerinde, akıllı telefonları kapalı olduğunda, yanlarında bulunmadığında ya da evde unuttuklarında, rahatsızlık durumu oluştuğu gözlemlenmektedir (Billieux vd., 2008: 1206). Ayrıca bu bireylerin sürekli olarak şarj cihazlarını yanlarında taşıdıkları, akıllı telefonlarını kaybetme korkusu içinde oldukları, akıllı telefonları yanlarında bulunmadığında ya da şebeke çekmediğinde, şarjları bittiğinde kendileriniendişeli ve gergin hissettikleri de gözlemlenen davranışlar arasında yer almaktadır. Akıllı telefon bağımlılığı gösteren bireyler sürekli olarak gönderilerin, mesajların, çağrıların alınıp alınmadığını kontrol etmek için akıllı telefonlarına bakar, 24 saat yanlarından akıllı telefonlarını ayırmazlar, hatta yatakta akıllı telefonları ile uyudukları da gözlemler sonucu elde edilen bulgular arasında yer almaktadır. Bu bireyler yüz yüze iletişim kurmaktan çekindikleri kişilerle akıllı telefonları aracılığı ile iletişim kurmayı tercih ederek sosyal etkileşimden uzak durmakta, akıllı telefona sahip olmak için büyük harcamalar yapmaktan sakınmamakta (Bragazzi ve Puente, 2014: 156-157; Göldağ, 2019: 198), hayali zil sesi duyma hissi ile ya da başkasının çalan telefon zil sesini kendi akıllı cihazının sesi ile karıştırabilmekte, bunun sonucu olarak hemen akıllı telefonlarını kontrol etme davranışı sergileyebilmektedirler (Bragazzi ve Puente, 2014: 157).

Bireylerin kullanılamadığı durumlarda rahatsızlık duymasına neden olan ve kullanım oranı giderek yaygınlaşan akıllı telefonların kontrolsüz kullanımının, kullanıcılar üzerinde istenmeyen sonuçlara neden olabileceği, onlar üzerinde olumsuz etkiler bırakabildiği görülmektedir. Örneğin bazı kullanıcılar araç kullanırken akıllı telefonlarını kullandıklarında kontrollerini kaybedip kaza yapabilmektedirler. Ayrıca akıllı telefonların aşırı kullanımı bağımlılığa dönüşmekte, çalışanların işlerinde verimliğini olumsuz etkileyebilmekte ve kişisel ve sosyal birtakım sorunları artırabilmektedir (Chen vd. 2017: 891).Akıllı telefonların aşırı kullanımı bireylerin sosyal etkileşimlerinden yoksun kalmasına, yüz yüze iletişim oranlarını azaltarak, onların çevreden izole olmalarına sebep olmakla beraber, fazla elektromanyetik alanda bulunma ve radyasyona maruz kalma nedeniyle fizyolojilerini olumsuz yönde etkilenmesine, akıllı telefonlarını kullanamama korkusuyla strese girmelerine neden olabilmektedir (Bragazzi ve Puente, 2014: 156). Ak1ll telefon kullanımının bağımlılık düzeyine gelmesi ile bireylerin alışkanlıkları, sosyal davranışları, aile ilişkileri ve sosyal etkileşimlerinin de etkilendiği, akıllı telefonlarını ve akıllı telefon uygulamalarını 24 saat boyunca 


\section{M. Özdemir - Nurcan Çetiner 13/2 (2021) 1679-1694}

sürekli kontrol etme ve kullanma durumlarının bireylerde uyku düzeninin bozulmasına, stres ve kayg1 yaşamalarına, akademik performansta düşüklüğe ve fiziksel aktivitelerin azalmasına neden olabildiği görülmektedir (Samah ve Hawi, 2016: 321).

İnsanların elektronik postalarını okuyabilmelerine, sosyal ağlara girerek sosyalleşme ihtiyaçlarını karşılayabilmelerine, internete daha hızlı ve kolayca erişim sağlayabilmelerine, işleri ile ilgili sorumluluklarını mekâna bağlı kalmaksızın yerine getirebilmelerine imkân tanıyan ve insan yaşamını kolaylaştıran akıllı telefon kullanımının her ne kadar olumsuz etkileri olsa da araştırmalar incelendiğindeiş yerinde akıllı telefonlar aracılı̆̆ıyla internet kullanımının çalışanlar üzerinde olumlu etkileri olduğu da gözlenebilmektedir.

Araştırma bulgularına göre çalışanların mesai saatleri içinde akıllı telefon kullanımlarının yoğun iş temposu sonucu çalışanlar üzerinde oluşan yorgunluk veya stresle mücadele edebilmelerinde yardımcı olduğu, işyerinde yaratıcılık, refah, eğlence ve iyileşmede artış ve tüm bunlara bağlı olarak daha mutlu çalışanlar olmalarında etkili olduğu, yüksek düzeyde iş tatminine sahip olma olasılıklarını artırmakta olduğu görülmektedir (Vitak vd., 2011: 1752; Özler ve Polat, 2012: 11).

\subsection{Işs Tatmini}

Örgütler hedef kitlelerini memnun edebilmek ve onların örgüte bağlı müşteriler olması için çaba göstermektedirler. Sunulan hizmetin kalitesi memnun müşteriler oluşturabilmenin unsurlarından biridir. Örgütlerde sunulan hizmetin kalitesini etkileyen unsurlardan biri ise örgütün sahip olduğu çalışanların işlerine karşı olan yaklaşımları ve tutumlarıdır. Bilinmektedir ki sürekli gelişen ve değişen dış çevrede rakiplerle mücadelede örgütlerin sahip oldukları en önemli unsur, birebir ikamesinin zor olduğu nitelikli çalışanlara sahip olmaktır. Örgütsel etkinliğin sağlanabilmesinde ise bu önemli kaynağın, yani örgüt çalışanlarının, iş tatmin düzeylerinin yüksek olması önem arz etmektedir.

Araştırmaları I. Dünya Savaşı yıllarına dayanan iş tatmini (Sökmen, 2020: 3467) ile ilgili sistematik çalışmalar 1930-1940 yıllarında kavramın önemi anlaşılarak gerçekleştirilmeye başlanmıştır (Agho vd., 1993: 1007; Eğinli, 2009: 36). İş tatmini; çalışanların örgütsel amaçlara ulaşmada istekli olmaları ve verimli biçimde katkı sağlayabilmeleridir (Tengilimoğlu, 2005: 27). Oshagbemi (2000: 331) iş tatminini; bireyin belirli bir işe karş1 olumlu duygusal tepkileriolarak ifade etmekte, çalışanların işleri sonucu elde ettikleri gerçek sonuçları istenen, beklenen veya hak edilenlerle karşılaştırmasından kaynaklanan işe karşı geliştirdikleri duyuşsal bir tepkimelerdir şeklinde açıklamaktadır. İş tatmini örgüt çalışanlarının işleri ile ilgili görüşlerinin dışa yansımasıdır (Sevim ve İşcan, 2005: 55).

Tanımlardan da anlaşılacağı üzeri iş tatmini; örgüt çalışanlarının işlerine karşı sergilemiş olduğu tutumlardır. Çalışanın beklentileri ile elde ettiklerinin kıyaslaması sonucu işine karşı gösterdikleri tepkimeler olarak da ifade edilebilmektedir.

Örgütlerde işinden tatmin olan çalışanların, örgütsel verimliliğe olan katkıda, örgütsel performansın artırılmasında, örgüte olan bağlllıklarının sağlanmasında, örgütsel hedeflere ulaşmada, işgücü devinim hızının düşmesinde, örgütsel vatandaşlık davranışının oluşmasında, sunulan hizmette ve elde edilen ürünlerde kalitenin artıılmasında katkısının yadsınamaz olduğu bir gerçektir (Tengilimoğlu, 2005: 27; Çalışkan ve Hazır, 2012: 49; Şen ve Mert, 2019: 16). Örgüt çalışanlarının aidiyet duygusu ile çalıştıkları örgütün amaç ve değerlerini benimsemesi olarak ifade edebileceğimiz örgütsel bağlllığı yüksek olan çalışanların iş tatminlerinin de yüksek olduğu görülmektedir (Alayvaz ve Keskin, 2020: 11). Yani iş tatmini örgütsel bağlllığa hem olumlu yönde etki etmekte hem de örgütsel bağlllıktan olumlu etkilenebilmektedir.

Alan yazın incelendiğinde araştırmacılar tarafından örgütlerde çalışanların yaş, cinsiyet, kişilik özellikleri, eğitim gibi bireysel faktörleri ilealınan ücret, denetim, yönetim tarzı, iş ortamlarının güvenliği, statü, etkili örgütsel iletişim, işin özellikleri, çalışma koşulları gibi örgütsel faktörlerin iş tatminini etkileyen unsurlar olarak ikiye ayrıldığı belirtilmektedir (Dodd ve Ganster, 1996: 340; Sevimli ve İşcan, 2005: 55; Sığrı ve Basım, 2006: 134; Örücü vd., 2006: 41). Çalışan personelin iş tatminini etkileyen faktörler arasında yönetim tarzı ve ücret faktörünün diğer faktörlere nazaran daha etkili olduğu görülmektedir (Örücü vd., 2006: 39). Ayrıca çalışanların işyerinde kıdemleri ve çalışma süreleri arttıkça işlerinden daha memnun oldukları, bu nedenle kıdem ve çalışma süresinin de çalışanların iş tatminlerini olumlu yönde etkilediği görülmektedir (Oshagbemi, 2000: 336). 
Endüstriyel ve örgütsel psikolojinin merkezinde yer alan iş tatmini kavramı, özellikle insan ilişkileri ve motivasyon teorisine dayandırılarak örgütlerin birincil hedefleri olarak görülmekte olup, işinden tatmin olmayan bireylerin örgütsel hedeflere ulaşmada engel teşkil edeceği, iş tatminsizliği yaşayan çalışanlarda işe devamsızlık, geç gelme, performans düşüklüğ̈̈u, iş kazalarında artış, verimlilikte düşük, örgüte olan bağlllı̆ın azalması, örgütsel amaçlara ulaşılamama, işlerin yavaşlaması gibi olumsuz sonuçlara yol açtığı bilinmektedir (Tengilimoğlu, 2005: 28; Eğinli, 2009: 36). Bu nedenle örgütlerin çalışanların işlerinden tatmin olup olmadıklarını belirlemeleri gerektiği ve tatminsizlik durumuna neden olan unsurları düzeltme yoluna gitmenin örgütlerin ve yöneticilerinin çıkarına olacağı belirtilmektedir (Henne ve Locke, 1985: 221).

Araştırmada örgütlerin çalışanlarının iş tatmin ya da tatminsizlik durumlarına neden olan unsurları saptayabilmelerine yardımcı olabilmek adına gelişen teknoloji ile beraber kullanım sıklığı artan ve neredeyse bağımlılık düzeyine gelen çalışanların akıllı telefon kullanımlarına bağlı olarak gelişen akıllı bağımlılık düzeylerinin iş tatminlerine etki edip etmediği sorunsalına yanıt aranmaktadır.

\section{Araştırma Yöntemi}

\subsection{Araştırmanın Amacl, Modeli ve Hipotezleri}

$\mathrm{Bu}$ araştırmada temel amaç, akıllı telefon bağımlılığının çalışanların iş tatminleri üzerinde etkisini belirlemeye çalışmaktır. Ayrıca çalışanların demografik özelliklerine göre onların akıllı telefon bağımlılık düzeylerinin ve iş tatmin düzeylerinin değişiklik gösterip göstermediği de incelenmiştir."Teknolojik gelişmelere paralel olarak kullanım alanları ve yoğunluğu her geçen gün değişen akıllı telefonların bağımlılık düzeyinde riskli oranda kullanımı çalışanların iş tatmin düzeylerine etki etmekte midir?", sorunsalından yola çıkılarak gerçekleştirilen araştırma ile ilgili alan yazın taraması sonucu değişkenler ve bu değişkenler arasında önceden yapılan çalışmaların bulgularından hareketle araştırma modeli ve hipotezleri aşağıdaki gibi oluşturulmuştur.

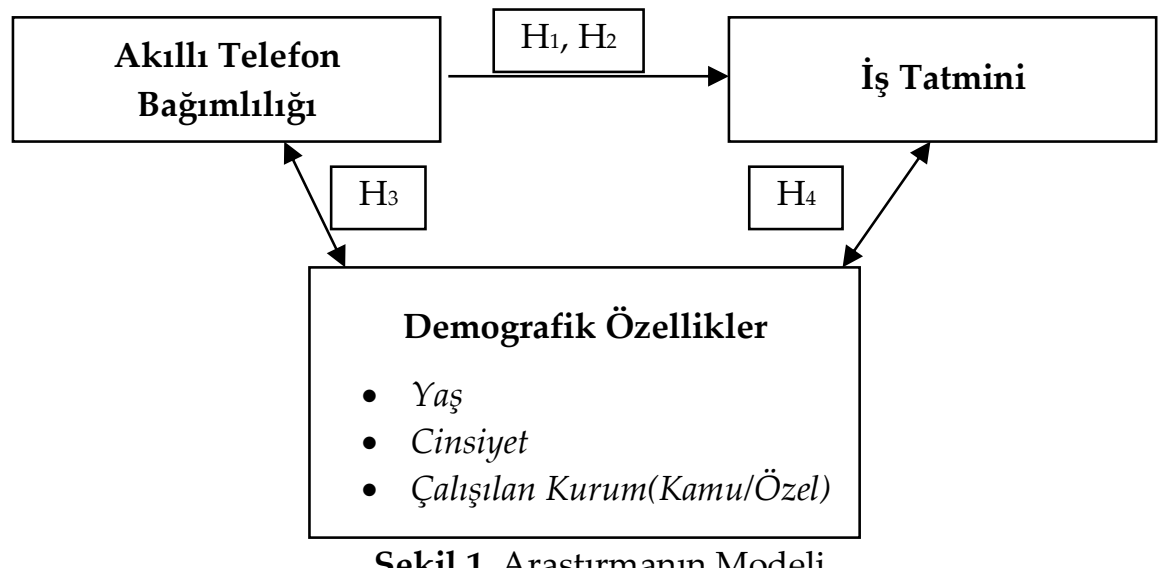

$\mathrm{H}_{1}$ : Çalışanların akıllı telefon bağımlılık düzeyleri ile iş tatminleri arasında anlamlı bir ilişki vardır.

$\mathrm{H}_{2}$ : Çalışanların akıllı telefon bağımlılık düzeylerine göre iş tatminleri farklılık göstermektedir.

$\mathrm{H}_{3}$ : Çalışanların demografik özelliklerine göre akıllı telefon bağımlılık düzeyleri farklılık göstermektedir.

$\mathrm{H}_{3 a:}$ Çalışanların cinsiyetlerine göre akıllı telefon bağımlılık düzeyleri farklılık göstermektedir.

$\mathrm{H}_{3 b}$ : Çalışanların çalıştıkları kuruma (kamu/özel) göre akıllı telefon bağımlılık düzeyleri farklılık göstermektedir.

$\mathrm{H}_{3 c}$ : Çalışanların yaşlarına göre akıllı telefon bağımlılık düzeyleri farklılık göstermektedir.

$\mathrm{H}_{4}$ : Çalışanların demografik özelliklerine göre iş tatmin düzeyleri farklılık göstermektedir.

$\mathrm{H}_{4 a}$ : Çalışanların cinsiyetlerine göre iş tatmin düzeyleri farklılık göstermektedir.

H4b: Çalışanların çalıştıkları kuruma (kamu/özel) göre iş tatmin düzeyleri farklılık göstermektedir.

$\mathrm{H}_{4 c}$ : Çalışanların yaşlarına göre iş tatmin düzeyleri farklılık göstermektedir. 


\subsection{Veri Toplama ve Örneklem Yapısı}

Görgül bir çalışma olan araştırmada konu hakkında alan yazın taraması yapılarak kavramsal çerçeve açıklanmış olup, araştırma verilerine ulaşmak için katılımcılara anket uygulaması yapılmıştır. Araştırma ile ilgili olarak Karamanoğlu Mehmet Bey Üniversitesi Bilimsel Araştırma ve Yayın Etiği Kurulunun 25.01.2021 tarih ve E-95728670-044-2670 sayı numaralı kararı ile etik kurul izni alınmıştır. Türkiye'de çalışan kişilere kolayda örnekleme yöntemi ile ulaşılmış, google form üzerinden oluşturulan anket linki (https:// docs. google. com/forms /dlel 1FAIp QLScqav OWYZVo4 YB8k2y 0ltXTGb 2B8873 lRUHWph6ZrDcehkqeA/viewform) aracıllğı ile ulaştırılan anket formu ile katılımcıların ankete katılmaları ve anket linkini kendi ağlarında paylaşmaları istenmiştir.Katılımcılardan Kasım 2020 - Ocak 2021 tarihleri arasında, toplam 497 adet geri dönüşs sağlanmış olup 14 adet anket verisinin analize uygun olmadığı tespit edildiğinden söz konusu veriler analize dâhil edilmemiş, analizler 483 veri üzerinden gerçekleştirilmiştir.

Araştırmanın evreni Türkiye' de çalışan, 18 yaş üzeri ve gelir sahibi olan bireylerden oluşmaktadır. Bu açıdan araştırmanın örneklemini kolayda örnekleme yöntemiyle ulaşılan 483 çalışan oluşturmaktadır. Örneklem büyüklüğünün değişken sayısının en az beş katı olması gerektiği (Büyüköztürk, 2002: 480) bilgisinden yola çıkılarak örneklem sayısının yeterli düzeyde olduğu görülmektedir.

\subsection{Veri Toplama Araçları}

Araştırmada katılımcıların demografik özellikleri ile ilgili olarak 8 sorudan oluşan demografik bilgi formu, iş tatmini ölçeği ve akıllı telefon bağımlılığı ölçeği kullanılmıştır. Katılımcıların akıllı telefon bağımlılığı riskinin düzeyini belirlemek ve yüksek risk grubunu ayırt edebilmek için Kwon vd., (2013) tarafından geliştirilen ve Noyan vd., (2015) tarafından Türkçeye uyarlanan Akıllı Telefon Bağımlılığı Ölçeğinin Kısa Formu kullanılmıştır. Ölçek 10 ifadeden ve tek faktörden oluşmaktadır. Ölçeğin Cronbach Alpha katsayısı 0,911'dir ve Türkçeye uyarlanmış halinin Cronbach Alpha katsayısı 0,867'dir ve güvenirlik düzeyinin yeterli olduğu ortaya konulmuştur.

Katılımcıların iş tatmin düzeylerinin ölçümünde ise 20 ifadeden oluşan Weiss vd., (1967) tarafından geliştirilen “İş Tatmini” Ölçeği kısa formdan faydalanılmıştır. Öztürk ve Aygün (2020: 219)'ün araştırmasında kullandığı "İ̧̧ Tatmini" Ölçeği kısa formunun Cronbach Alfa katsayısının, 925 ve güvenilirlik düzeyinin yeterli olduğu ortaya konulmuştur.

Tüm ölçeklerdeki ifadeler beşli likert ölçeği ile yapılandırılmıştır. Beşli likert ile derecelendirilen ölçeklerde 1= Kesinlikle Katılmiyorum; 2= Katılmıyorum, 3=Ne Katılıyorum/Ne Katılmıyorum, 4= Katılıyorum, 5= Kesinlikle Katılıyorum şeklinde yapılandırılmıştır. 4/5=0,80 formülünden yola çıkılarak 1.00-1.79 Kesinlikle Katılmıyorum (oldukça düşük), 1.80-2.59 Katılmıyorum (düşük), 2.60 - 3.39 Ne Katılıyorum/Ne Katılmıyorum (orta), 3.40-4.19 Katıllyorum (yüksek), 4.20-5.00 Kesinlikle Katılıyorum (oldukça yüksek) olarak değerlendirilmiştir.

\subsection{Verilerin Analizi}

Çalışmada verilerin analizinde SPSS 21.0 programı kullanılmıştır. Elde edilen araştırma verileri doğrultusunda değişkenler arasında karşılaştırma yapmadan önce, verilerin normallik sınamaları test edilmiştir. Örneklem sayısı 30' dan büyük olduğu için $(n=483)$ Kolmogorov-Smirnov verilerine bakılmış olup Tablo 1'deki veriler elde edilmiştir.

Tablo 1. Ölçeklerin Normallik Sınamaları

\begin{tabular}{|l|c|c|c|c|c|}
\hline \multicolumn{7}{|c|}{ Kolmogorov-Smirnov } \\
\hline & Statistic & Sd & Sig. & Çarpıklık & Basıklık \\
\hline İş Tatmini &, 089 & & 0,000 &, 478 & 1,424 \\
\hline Akııllı Telefon Bağımlılığı &, 082 & 483 & 0,000 &, 615 &, 034 \\
\cline { 6 - 7 } & & & &
\end{tabular}




\section{M. Özdemir - Nurcan Çetiner 13/2 (2021) 1679-1694}

Tablo 1'de görüleceği üzere yapılan normallik sınaması sonucunda her değişken için elde edilen KolmogorovSmirnov değerlerinin $p<0,05$ olmasından dolayı verilerin normal dağılmadığı görülmektedir. Ancak likert tipi ölçeklerin kullanıldığı çalışmalarda, Kolmogorov-Smirnov testlerinde p değeri genellikle 0,05 değerinden küçük olacağından, verilerin normal dağılıp dağılmadığını belirleyebilmek için ölçek verilerinin çarpıklık (Skewness) ve basıklı (Kurtosis) değerleri incelenmektedir (Saruhan ve Özdemirci, 2016: 241). Bununla birlikte Tabachnick ve Fidell'e göre (2013: 79) çarpıklık ve basıklık değerlerinin -1.5 ve +1.5 değer arasında olması verilerin normal dağıldığının göstergesidir. Araştırma sonucu elde edilen 483 veri üzerinde gerçekleştirilen normallik analizi sonucunda iş tatmini ve akıllı telefon bağımlılığı ölçeğinin KolmogorovSmirnov değerlerinin $p<0,05$ olmasına karşın, çarpıklık ve basıklık değerlerinin ilgili aralıkta olması sonucu, verilerin normal dağıldığı söylenebilmektedir.

Verilerin normal dağılması sonucu çalışma kapsamında parametrik analizlerin kullanılması uygun görülmektedir.

Araştırmada kullanılan ölçeklerin güvenirliğinin belirlenmesinde Cronbach Alfa katsayısından yararlanılmıştır. Ölçeklerin yapı geçerliğinin incelenmesinde her bir ölçeğin yapı geçerliliğini sınamak için keşfedici faktör analizi uygulanmıştır. Yapılan faktör analizlerinde Direct Oblimin tekniği kullanılmıştır. Tablo 2, ölçeklere ilişkin keşfedici faktör analizi ve güvenirlik analizi bulgularını içermektedir. Ölçeklerin güvenirlik katsayıları $(, 81<\alpha<1,00)$ aralığında olduğu için tüm ölçekler yüksek düzeyde güvenilir niteliktedir (Yaşar, 2014: 63).

Tablo 2. Ölçeklerin Keşfedici Faktör Analizi ve Güvenirlik Analizi Bulguları

\begin{tabular}{|c|c|c|c|}
\hline Ölçek & Madde Sayısı & Açılkanan Varyans (\%) & $\begin{array}{c}\text { Cronbach Alpha } \\
\qquad(\alpha)\end{array}$ \\
\hline \multirow{2}{*}{ 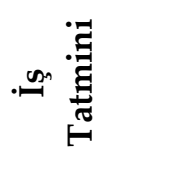 } & 20 & 24,881 & 0,836 \\
\hline & \multicolumn{3}{|c|}{ KMO: ,833; Bartlett: 5566,187; df:190; p<0,001 } \\
\hline \multirow{2}{*}{ 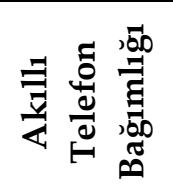 } & 10 & 53,899 & 0,904 \\
\hline & \multicolumn{3}{|c|}{ KMO: ,888; Bartlett: 2881,871; df:45; p<0,001 } \\
\hline
\end{tabular}

Tablo2'de görüleceği üzere İş tatmini ölçeğinin keşfedici faktör analizi bulguları incelendiğinde KMO örneklem yeterliği katsayısı ,833 ve Bartlett Küresellik Testi $(\mathrm{p}<, 001)$ anlamlıdır. Analiz sonucu elde edilen verilere göre, örneklem büyüklüğünün faktör analizi için yeterli ve ölçme aracının faktör analizi yapmaya uygun olduğu sonucu görülmektedir. KMO değeri 0,81-0,90 aralığında olduğu zaman analizin yapıldığı örneklemin boyutu "iyi" niteliktedir (Yaşar, 2014: 66). Toplam ifade sayısı 20 olan iş tatmini ölçeği tek faktör yapısına sahiptir ve ölçeğe ilişkin açılanan toplam varyans $\% 24,881^{\prime}$ dir. Ölçeğin güvenirlik düzeyi ise Cronbach Alfa katsayısı ile değerlendirilmiştir. Ölçeğin güvenirlik değeri $(\alpha=, 836)$ yüksek düzeydedir.

Akıllı telefon bağımlılığı ölçeğinin keşfedici faktör analizi bulguları incelendiğinde KMO örneklem yeterliği katsayısı ,888 ve Bartlett Küresellik Testi $(\mathrm{p}<, 001)$ anlamlıdır. Analiz sonucu elde edilen verilere göre, örneklem büyüklüğünün faktör analizi için yeterli ve ölçme aracının faktör analizi yapmaya uygun olduğu sonucu görülmektedir. KMO değeri 0,81-0,90 aralığında olduğu zaman analizin yapıldığı örneklemin boyutu "iyi" niteliktedir (Yaşar, 2014: 66). Toplam ifade sayısı 10 olan akıllı telefon bağımlılığı ölçeği tek faktör yapısına sahiptir ve ölçeğe ilişkin açıklanan toplam varyans \%53,899'dir. Ölçeğin güvenirlik düzeyi ise Cronbach Alfa katsayısı ile değerlendirilmiştir. Ölçeğin güvenirlik değeri $(\alpha=, 904)$ yüksek düzeydedir. 


\section{Bulgular}

Ölçeklerin güvenirlik ve geçerlilik analizlerinin ardından katılımcılara ait demografik bilgilere ait veriler Tablo 3'te verilmiştir.

Tablo 3. Katılımcılara Ait Demografik Bilgiler

\begin{tabular}{|l|c|c|c|}
\hline & Frekans & Yüzde Oran1 \% & Kümülatif Yüzde Oranı \\
\hline Cinsiyet & & & 61,7 \\
\hline Kadın & 298 & 61,7 & 100,0 \\
\hline Erkek & 185 & 38,3 &, 4 \\
\hline Yaş & 2 & & 71,2 \\
\hline 21 yaş & 342 & 0,4 & 97,7 \\
\hline $22-39$ & 128 & 70,8 & 100 \\
\hline $40-55$ & 11 & 26,5 & 63,8 \\
\hline $56-74$ & & 2,3 & 100,0 \\
\hline Çalıştı̆̆1 Kurum & 308 & & \\
\hline Kamu & 175 & 63,8 & \\
\hline Özel Sektör & $\mathbf{4 8 3}$ & 36,2 & $\mathbf{1 0 0}$ \\
\hline Toplam & & & \\
\hline
\end{tabular}

Araştırma sonucu elde edilen veriler 1şığında araştırmaya katılımcıların \%61,7'si kadın, \%38,3'ü erkektir. Katılımciların \%63,8'i kamu, \%36,2'si özel sektörde çalı̧̧maktadır. Katılımcıların \%70,8'i 22-39 yaş arasında, $\% 26,5^{\prime}$ i 40-55 yaşları arasındadır.

Tablo 4. Ölçeklerin Betimsel İstatistikleri

\begin{tabular}{|l|c|c|c|c|r|r|}
\hline Ölçek & $\mathbf{N}$ & Min. & Maks. & Ort & Std. Sapma & Varyans \\
\hline İş Tatmini & 483 & 1,70 & 4,90 & 3,1708 &, 47009 &, 221 \\
\hline $\begin{array}{l}\text { Akıllı Telefon } \\
\text { Bağımlığı }\end{array}$ & 483 & 1,00 & 4,90 & 2,2836 &, 85731 &, 735 \\
\hline
\end{tabular}

Tablo4'te görüleceği üzere katılımcıların iş tatmin düzeylerinin 3,1708 ortalama ile orta düzeyde olduğu, akıllı telefon bağımlılık düzeylerinin 2,2836 ortalama ile düşük düzeyde olduğu söylenebilmektedir.

Çalışmanın betimsel analizlerinden sonra hipotezleri sınamak amacıyla analizler yapılmış ve elde edilen bulgular paylaşılmıştır.

Tablo 5. İş Tatmini ve Akıllı Telefon Bağımlılığı Arasındaki İlişki

\begin{tabular}{|c|c|c|c|}
\hline & & 1 & 2 \\
\hline \multirow{3}{*}{ 1-İş Tatmini } & Pearson Correlation & 1 & \\
\hline & Sig. (2-tailed) & & \\
\hline & $\mathrm{N}$ & 483 & \\
\hline \multirow{3}{*}{ 2-Akıllı Telefon Bağımlılığı } & Pearson Correlation &, $598^{* *}$ & 1 \\
\hline & Sig. (2-tailed) & 000 & \\
\hline & $\mathrm{N}$ & 483 & 483 \\
\hline
\end{tabular}

Tablo 5 'te de görüleceği üzere yapılan korelasyon analizi sonucunda çalışanların akıllı telefon bağımlılığı ile iş tatmini algısı arasında $\mathrm{p}<0,01$ düzeyinde pozitif yönde ve anlamlı bir ilişki bulunmuştur $(\mathrm{r}=$,598). İki değişken arasındaki ilişkinin miktarını yorumlamak için korelasyon katsayısını ifade eden " $\mathrm{r}$ " kullanılır. Korelasyon katsayısının 1.00 olması mükemmel pozitif ilişkiyi; -1.00 olması mükemmel negatif ilişkiyi; 0.00 


\section{M. Özdemir - Nurcan Çetiner 13/2 (2021) 1679-1694}

olması ilişki olmadığını göstermektedir. Korelasyon katsayısının 0.70-1.00 arasında olması yüksek; 0.70-0.30 arasında olması orta ve 0.30 ' dan düşük olması ise, düşük düzeyde bir ilişkiyi ifade etmektedir (Baykul ve Güzeller, 2014: 577; Saruhan ve Özdemirci, 2016: 184).

Bu bilgiler ışığında akıllı telefon bağımlılı̆̆ı ile iş tatmini algısı arasındaki ilişkinin kuvvetinin orta düzeyde, anlamlı ve olumlu olduğu görülmektedir. Korelasyon analizi sonuçlarına göre "H1: Çalışanların akıllı telefon bağımlılık düzeyleri ile iş tatminleri arasında anlamlı bir ilişki vardır" hipotezi istatistiki olarak desteklenmiştir.

Akıllı telefon bağımlılığının ile iş tatmini üzerindeki etkinin düzeyini test etmek için ise regresyon analizi yapılmıştır.

Tablo 6. Akıllı Telefon Bağımlılığının İş Tatmini Üzerine Etkisine İlişkin Regresyon Modeli

\begin{tabular}{|c|c|c|c|c|c|c|c|}
\hline \multicolumn{8}{|c|}{ Model Özeti } \\
\hline & Model & $\mathbf{R}$ & $\mathbf{R}^{2}$ & $\begin{array}{c}\text { Düzeltilmiş } \\
\mathbf{R}^{2}\end{array}$ & \multicolumn{3}{|c|}{ Tahminin Standart Hatası } \\
\hline & 1 &, $598^{a}$ &, 357 & ,356 & & 37721 & \\
\hline \multicolumn{8}{|c|}{ ANOVA $^{b}$} \\
\hline & Model & Kareler Toplamı & sd & $\begin{array}{l}\text { Ortalama } \\
\text { Kare }\end{array}$ & $\mathbf{F}$ & \multicolumn{2}{|c|}{ Sig. } \\
\hline \multirow{3}{*}{1} & Regresyon & 38,075 & 1 & 38,075 & 267,596 & &, $000^{\mathrm{a}}$ \\
\hline & Artık (Residual) & 68,439 & 481 & , 142 & & & \\
\hline & Toplam & 106,513 & 482 & & & & \\
\hline \multicolumn{8}{|c|}{ Katsayılarb } \\
\hline \multirow{2}{*}{\multicolumn{2}{|c|}{ Model }} & Std. Edilmemiş K & Catsayılar & \multirow{2}{*}{\multicolumn{2}{|c|}{$\begin{array}{c}\text { Std. Edilmiş Katsayılar } \\
\text { Beta }\end{array}$}} & \multirow{2}{*}{$\mathbf{t}$} & \multirow{2}{*}{ Sig. } \\
\hline & & $\beta$ & Std. Hata & & & & \\
\hline \multirow[b]{2}{*}{1} & Sabit & 2,422 & ,049 & & & 49,554 & ,000 \\
\hline & $\begin{array}{c}\text { Akıllı } \\
\text { Telefon } \\
\text { Bağımlılığ } 1\end{array}$ & ,328 & ,020 & ,598 & & 16,358 & ,000 \\
\hline & $\begin{array}{l}\text { redictors: (Sabit), } \\
\text { Bağımlı Değişken: }\end{array}$ & $\begin{array}{l}\text { l1 Telefon Bağımlıl } \\
\text { tmini }\end{array}$ & & & & & \\
\hline
\end{tabular}

Tablo 6'da görüleceği üzere $R$ değeri korelasyon analizinde de bulunan ve ilişkinin gücünü gösteren ,598 değeridir. Bununla birlikte tabloda akıllı telefon bağımlılık düzeyinin iş tatmini algısının varyansını yaklaşık olarak \%35,7 oranında açıkladığı bulunmuştur. ANOVA ve katsayılar kısmında anlamlılık sütunları incelendiğinde modelin ve bağımsız değişken olan akıllı telefon bağımlılığının $p<0,01$ düzeyinde istatistikî olarak anlamlı olduğu görülmektedir.

Katsayı kısmına bakıldığında ise denklemin sabit değerinin 2,422 olduğunu, akıllı telefon bağımlılı̆̆1 katsayısının ise ,328 olduğu görülmektedir. Yani akıllı telefon bağımlılık düzeyindeki her 1 (bir) birimlik artış, iş tatmini algısında ,328'lik bir artışın olacağını göstermektedir. Bu bağlamda regresyon modeli aşağıdaki biçimde formüle edilebilmektedir:

\section{İş Tatmini Algısı= 2,422+0,328 * Akıllı Telefon Bağımlılığ}

Akıllı telefon bağımlılık düzeyi ile iş tatmin düzeyi arasında ilişkinin anlamlı çıkması sonucu, çalışanların akıllı telefon bağımlılık düzeylerinin (düşük, orta, yüksek) iş tatminleri üzerine etkisini incelemek amacıyla One-Way ANOVA analizi yapılmıştır. 
M. Özdemir - Nurcan Çetiner 13/2 (2021) 1679-1694

Tablo 7. Akıllı Telefon Bağımlılık Düzeylerine Göre İş Tatminine Yönelik Anova Analizi

\begin{tabular}{|c|c|c|c|c|c|}
\hline $\begin{array}{l}\text { Akıllı telefon } \\
\text { Bağımlılık } \\
\text { Düzeyleri }\end{array}$ & $\mathbf{N}$ & Ort. & $\begin{array}{c}\text { Standart } \\
\text { Sapma }\end{array}$ & F & P \\
\hline Düşük & 328 & 3,0128 &, 40808 & & \\
\hline Orta & 100 & 3,3620 &, 34838 & \multirow{2}{*}{99,841} & \multirow{2}{*}{000} \\
\hline Yüksek & 55 & 3,7655 &, 40252 & & \\
\hline Toplam & 483 & 3,1708 &, 47009 & & \\
\hline
\end{tabular}

Tablo 7'de görüleceği üzere, Levene istatistiğinin $p$ değeri $(p=, 801)$ grup varyanslarının eşit dağıldığını göstermektedir. Anova analiz sonuçları incelendiğinde $(p<0,01)$ katılımcıların akıllı telefon bağımlılık düzeylerine (düşük, orta, yüksek) göre iş tatminlerinde istatistiki olarak anlamlı farklılıklar olduğu görülmektedir. Bu sonuçla birlikte " $\mathrm{H}_{2}$ : Çalışanların akıllı telefon bağımlılık düzeylerine göre iş tatminleri farklılık göstermektedir." hipotezi istatistikî olarak desteklenmiştir.

Bununla birlikte hangi düzeyde katılımcılar arasında iş tatmin düzeyi bağlamında fark olduğunu belirlemek amacıyla grup varyanslarının eşit dağıldığından dolayı PostHoc Testlerinden Scheffe testi yapılmıştır.

Tablo 8. İş Tatmininin Akıllı Telefon Bağımlılık Düzeyleri Açısından Farklılığında Scheffe Testi Sonuçları

\begin{tabular}{|l|l|c|c|c|}
\hline ATB (I) & ATB (J) & Ortalama Farkı (I - J) & Std. Hata & Sig. \\
\hline \multirow{2}{*}{ Düşük } & Orta &,$- 34920^{*}$ &, 04522 &, 000 \\
\cline { 2 - 5 } & Yüksek &,$- 75265^{*}$ &, 05768 &, 000 \\
\hline \multirow{2}{*}{ Orta } & Düşük &, $34920^{*}$ &, 04522 &, 000 \\
\cline { 2 - 5 } & Yüksek &,$- 40345^{*}$ &, 06646 &, 000 \\
\hline \multirow{2}{*}{ Yüksek } & Düşük &, $75265^{*}$ &, 06768 &, 000 \\
\cline { 2 - 5 } & Orta &, $40345^{*}$ & & \\
\hline
\end{tabular}

Scheffe testinin sonuçlarına göre düşük düzeyde akıllı telefon bağımlılığına sahip katılımcıların iş tatmin düzeyleri ile orta ve yüksek düzeyde akıllı telefon bağımlılı̆̆ına sahip katılımcıların iş tatmin düzeylerinin anlamlı bir şekilde farklılık gösterdiği görülmektedir. İş tatmin ortalamalarına bakıldığında ise düşük düzeyde akıllı telefon bağımlılığına sahip katılımcıların 3,0128; orta düzeyde akıllı telefon bağımlılığına sahip katılımcıların 3,3620 ve yüksek düzeyde akıllı telefon bağımlılığına sahip katılımcıların 3,7655 ortalamaya sahip olduğu görülmektedir. Bu durumda yüksek düzeyde akıllı telefon bağımlılığına sahip katılımcıların iş tatmin düzeylerinin en yüksek olduğu görülmektedir. Bu üç düzey akıllı telefon bağımlılığı ele alındığında akıllı telefon bağımlılık düzeyleri arttıkça iş tatmin düzeylerinin doğru orantılı olarak arttığı görülmektedir.

Çalışanların akıllı telefon bağımlılık düzeyleri ile iş tatmin düzeylerinin çalışanların cinsiyete ve çalıştığı kuruma (kamu/özel) göre farklılık gösterip göstermediğini analiz etmek için, her iki faktörün de iki düzeyinin olmasından dolayı, bağımsız örneklem t-testi yapılmıştır.

Tablo 9. Çalışılan Kurum ve Cinsiyete Göre İş Tatmini ve Akıllı Telefon Bağımlılığındaki Farklılaşma

\begin{tabular}{|c|c|c|c|c|c|c|c|}
\hline & & & $\mathbf{N}$ & Ort. & S.S. & $\mathbf{t}$ & $\mathbf{P}$ \\
\hline \multirow{5}{*}{ İş Tatmini } & \multirow{2}{*}{ Cinsiyet } & Kadın & 298 & 3,1503 & ,42815 & \multirow{2}{*}{$-1,157$} & \multirow{2}{*}{ 248 } \\
\hline & & Erkek & 185 & 3,2038 & ,53029 & & \\
\hline & \multirow{2}{*}{ Kurum } & Kamu & 308 & 3,1679 & ,47258 & \multirow{2}{*}{-183} & \multirow{2}{*}{855} \\
\hline & & Özel & 175 & 3,1760 & 46698 & & \\
\hline & Cinsiyet & Kadın & 298 & 2,2721 & ,82654 &,- 374 & 709 \\
\hline
\end{tabular}




\begin{tabular}{|c|c|c|c|c|c|c|c|}
\hline \multirow{3}{*}{$\begin{array}{c}\text { Akıllı Telefon } \\
\text { Bağımlılığı }\end{array}$} & \multirow{2}{*}{ Kurum } & Erkek & 185 & 2,3022 &, 90668 & & \\
\cline { 3 - 8 } & & Kamu & 308 & 2,3205 &, 86141 & \multirow{2}{*}{1,253} & \multirow{2}{*}{, 211} \\
\cline { 3 - 7 } & Özel & 175 & 2,2189 &, 84862 & & \\
\hline
\end{tabular}

Tablo 9'da görüleceği üzere yapılan analiz neticesinde sig değeri $(p>0,05)$ istatistikî olarak anlamlı olmadığ1 için katılımcıların akıllı telefon bağımlılık düzeyleri ve iş tatminlerinin cinsiyet ve çalışılan kuruma bağlı olarak anlamlı bir farklılık göstermediği bulunmuştur. Bu sonuçla birlikte "Hзa: Çalışanlarnn cinsiyetlerine göre akıllı telefon bağımlılık düzeyleri farklılık göstermektedir", "Hзs: Çalışanların çalıştıkları kuruma (kamulözel) göre akıllı telefon bağımlılık düzeyleri farklilık göstermektedir", "H4a: Çalı̧̧anların cinsiyetlerine göre iş tatmin düzeyleri farklilık göstermektedir", "H4b: Çalışanların çalıştıkları kuruma (kamu/özel) göre iş tatmin düzeyleri farklılık göstermektedir" hipotezleri istatistikî olarak desteklenememiştir.

Çalışanların iş tatmin düzeylerinin çalışanların yaşlarına göre farklılık gösterip göstermediğini analiz etmek için, yaş faktörünün iki düzeyden fazla düzeye sahip olmasından dolayı, Tek Yönlü Varyans (One-Way ANOVA) Analizi yapılmıştır.

Tablo 10. Katılımcıların Yaşlarına Göre İş Tatmini Düzeylerindeki Farklılaşma

\begin{tabular}{|c|c|c|c|c|c|}
\hline Yaş & $\mathbf{N}$ & Ort. & S. S. & $\mathbf{F}$ & $\mathbf{P}$ \\
\hline 21 yaş & 2 & 2,9250 & ,53033 & \multirow{5}{*}{2,260} & \multirow{5}{*}{,081 } \\
\hline 22-39 & 342 & 3,1963 & ,47861 & & \\
\hline 40-55 & 128 & 3,0914 & ,42325 & & \\
\hline 56-74 & 11 & 3,3455 & 62308 & & \\
\hline Total & 483 & 3,1708 & ,47009 & & \\
\hline
\end{tabular}

Tablo 10'da görüleceği üzere yapılan analiz neticesinde sig değeri $(p>0,05)$ istatistikî olarak anlamlı olmadığı için katılımcıların çalışanların yaşlarına bağlı olarak iş tatminlerinin anlamlı bir farklılık göstermediği bulunmuştur. Bu sonuçla birlikte "H4c: Çalışanlarn yaşlarına göre iş tatmin düzeyleri farklllık göstermektedir." hipotezi istatistikî olarak desteklenememiştir.

Çalışanların akıllı telefon bağımlılık düzeylerinin çalışanların yaşlarına göre farklılık gösterip göstermediğini analiz etmek için, yaş faktörünün iki düzeyden fazla düzeye sahip olmasından dolayı, Tek Yönlü Varyans (One-Way ANOVA) Analizi yapılmıştır.

Tablo 11. Katılımcıların Yaşlarına Göre Akıllı Telefon Bağımlılık Düzeylerindeki Farklılaşma

\begin{tabular}{|c|c|c|c|c|c|}
\hline Yaş & $\mathbf{N}$ & Ort. & S. S. & $\mathbf{F}$ & $\mathbf{P}$ \\
\hline 21 yaş & 2 & 2,3500 & ,77782 & \multirow{5}{*}{2,613} & \multirow{5}{*}{ 051 } \\
\hline 22-39 & 342 & 2,3363 & ,86711 & & \\
\hline $40-55$ & 128 & 2,1148 & 79299, & & \\
\hline $56-74$ & 11 & 2,6000 & 1,08167 & & \\
\hline Total & 483 & 2,2836 & ,85731 & & \\
\hline
\end{tabular}

Tablo 11'de görüleceği üzere yapılan analiz neticesinde sig değeri $(p>0,05)$ istatistikî olarak anlamlı olmadığ1 için katılımcıların akıllı telefon bağımlılık düzeyleri çalışanların yaşlarına bağlı olarak anlamlı bir farklılık göstermediği bulunmuştur. Bu sonuçla birlikte " $\mathrm{H}_{3}$ : Çalışanların yaşlarına göre akıllı telefon bağımlılık düzeyleri farkllık göstermektedir", hipotezi istatistikî olarak desteklenememiştir.

\section{Sonuç ve Tartışma}

Araştırmada çalışanların, akıllı telefon bağımlılık düzeylerinin, iş tatminleri üzerine etkisi ile çalışanların demografik özelliklerine göre akıllı telefon bağımlılık düzeyleri ve iş tatmin düzeylerinin değişiklik gösterip göstermediğini belirlemek amaçlanmıştır. 


\section{M. Özdemir - Nurcan Çetiner 13/2 (2021) 1679-1694}

Araştırma kapsamında elde edilen verilerin SPSS-21 programında kaydedilmesinin ardından hem iş tatmini ölçeği hem de akıllı telefon bağımlığı ölçeğinin geçerlilikleri için faktör analizleri ve ayrıca güvenilirlik analizleri gerçekleştirilmiştir. İş tatmini ve akıllı telefon bağımlılığı ölçeği için gerçekleştirilen faktör analizi neticesinde, her iki ölçek için orijinal ölçekleri ile uyumlu bir yapı elde edilmiştir. Bunun yanı sıra her iki ölçeğin güvenilirliği de yüksek düzeyde tespit edilmiştir.

Araştırmada elde edilen verilerin analizi sonucunda çalışanların orta düzeyde iş tatminine, düşük düzeyde akıllı telefon bağımlılık düzeyine sahip oldukları, çalışanların akıllı telefon bağımlılık düzeyi ile iş tatmin düzeyi arasında ilişkinin anlamlı, orta düzeyde ve olumlu olduğu, yüksek düzeyde akıllı telefon bağımlılık düzeyine sahip katılımcıların iş tatmin düzeylerinin en yüksek olduğu sonucuna ulaşılmıştır.Kısaca ifade etmek gerekirse akıllı telefon bağımlılığı ele alındığında çalışanların akıllı telefon bağımlılık düzeyleri arttıkça iş tatmin düzeylerinin doğru orantılı olarak arttığı sonucuna ulaşılmıştır. Alan yazın incelendiğinde çalışanların işyerlerinde internet ve mobil teknolojilerini kullanmalarının onların üzerinde olumlu etki yarattığı (Candan ve İnce, 2016: 230), işleri ile ilgili yaşadıkları sorunlarla başa çıkmalarında yardımcı olduğu, daha iyi çalışanlar olmalarına katkı sağladığı sonuçlarına ulaşıldığı görülmektedir. Çalışma saatleri içinde gerçekleştirilen işle ilgili olmayan tüm çevrimiçi faaliyetlerin çalışanlar için işlevsiz olmadığı, tam tersine çalışanların yoğun iş temposundan bir nebze olsun uzaklaşarak onlara nefes alma şansı tanıdığı ve çalışanları daha iyi performans göstermeleri için motive etmede yardımcı olabildiği ve bu sayede iş üzerinde olumlu bir etkisi olduğu (Lim ve Chen, 2009: 9), çalışanların üretkenliğini artırmaya yardımcı olabileceği görülmektedir (Lim ve Chen, 2012: 343). Urgin vd., (2002: 77) çalışmalarında örgütlerde mesai saatleri içinde mobil teknolojileri kullanan çalışanların yüksek düzeyde iştatminine sahip çalışanlar olma olasılıklarının daha yüksek olduğu sonucuna ulaşmışlardır. Ayrıca çalışanların yoğun iş temposu sonucu oluşan can sıkıntısı, yorgunluk veya stresten kurtulmalarına yardımcı olma, daha fazla iş tatmini, işyerinde yaratıcılık, refah, eğlence ve iyileşmede artış ve tüm bunlara bağlı olarak daha mutlu çalışanlar olmalarında etkilidir (Vitak vd., 2011: 1752). Blanchard ve Henle (2008: 1069) çalışmalarında, işyerinde çalışanların iş dışı internet ve mobil teknolojileri kullanımlarının iş yerinde yaratıcılığa, esnekliğe yardımcı olabileceği ve bir öğrenme ortamını geliştirebileceğini savunmaktadırlar. Bu bilgiler ışığında her ne kadar akıllı telefon bağımlılığının olumsuz etkileri olsa da olumlu etkileri olduğu da kabul edilebilir. Çalışanların akıllı telefonlarını kullanarak internet ve sosyal ağlara kolayca bağlanabildikleri için sosyal hayatla bağlarını koparmadıkları, akıllı telefonların getirdiği kullanım imkânları ve kolaylıklara paralel olarak işlerini daha hızlı yapmalarına imkân vermesi, mekâna bağlı kalmadan çalışmalarına, kendilerinden beklenilen görev ve sorumlulukları yerine getirmelerine olanak sağlaması gibi avantajların çalışanların işlerinde yaşadıkları tatmin duygularına olumlu yansıması, analiz sonucu ulaştığımız çalışanların akıllı telefon bağımlılık düzeyleri arttıkça iş tatmin düzeyleri de artmaktadır sonucunu destekler niteliktedir.

Analiz sonucunda çalışanların cinsiyetlerine göre akıllı telefon bağımlılık düzeylerinin anlamlı bir farklılık göstermediği sonucuna ulaşılmıştır. Elde edilen sonuç alan yazında erişilen Göldağ (2019: 202)'ın çalışmasının bulguları ile örtüşmekte olup, çalışmada araştırmaya katılan öğrencilerin akıllı telefon bağımlık düzeylerinin cinsiyete göre istatistiksel olarak anlamlı bir farklılık olmadığı sonucuna ulaşıldığı gözlenmektedir. Kozan vd.'nin (2019: 279) çalışmasında da öğrencilerin akıllı telefon bağımlık düzeylerinin cinsiyete göre istatistiksel olarak anlamlı bir farklılık olmadığı sonucuna ulaşılmıştır. Benzer şekilde Minaz ve Bozkurt (2017: 268) araştırmaları sonucunda cinsiyet ile öğrencilerin akıllı telefon bağımlılık düzeyleri arasında anlamlı bir farklılık bulunmadığı sonucuna ulaşmışlardır. Demografik özellikler içerisinde yer alan çalışanların cinsiyetleri onların akıllı telefon bağımlılık düzeylerine etki etmemektedir, dolayısı ile kadın olsun erkek olsun bireylerin akıllı telefon bağımlılık düzeyleri belirlenirken, cinsiyet faktörü etkin rol oynamamaktadır sonucuna varılabilir.

Analiz sonucunda çalışanların demografik özelliklerinden çalıştıkları kurum (kamu/özel) ile iş tatmin düzeyleri ve akıllı telefon bağımlılık düzeyleri arasında anlamlı bir farklılık olmadığı sonucuna ulaşılmışken, iş tatmin düzeylerinin demografik özelliklerden cinsiyete bağlı olarak anlamlı bir farklılık göstermediği de görülmektedir. Eyel ve Tutcu (2020: 3604) çalışmalarında iş tatmininin cinsiyete göre farklılaşmadığı sonucuna ulaşmışlardır. Benzer şekilde Oshagbemi (2000: 338) çalışmasında cinsiyetin iş tatmini üzerindeki etkileri konusunda, cinsiyetin tek başına iş tatminini etkilemediği sonucuna ulaşmıştır. Tekne ve Güney (2020: 143), Özaydın ve Özdemir (2014: 274) de çalışmalarında çalışanların cinsiyetleri ile iş tatminleri arasında anlamlı bir farklılık olmadığı sonucuna ulaşmışlardır. Elde edilen sonucun alan yazında erişilen sonuçlarla örtüşmekte 


\section{M. Özdemir - Nurcan Çetiner 13/2 (2021) 1679-1694}

olduğu görülmekte olup, çalışanların işlerinde tatmin duygusu hissedip hissetmemelerinde cinsiyetlerinin etken rol oynamadığı sonucuna varılabilir.

Çalışanların yaşlarına göre iş tatmin düzeyleri ve akıllı telefon bağımlılık düzeyleri arasında anlamlı bir farklılık olmadığı sonucuna ulaşılmıştır. Tekne ve Güney (2020: 143) çalışanların yaşlarına göre iş tatmin düzeylerinde anlamlı bir farklılık olduğu sonucuna ulaşmışlardır. Benzer şekilde Özaydın ve Özdemir (2014: 274) çalışmalarında banka çalışanlarının yaşları arttıkça iş tatmin düzeylerinde anlamlı farklılık oluştuğu, genç iş görenlerin yaşlı iş görenlere oranla daha düşük iş tatmin düzeyine sahip olduğu sonucuna ulaşmışlardır. Elde edilen sonucun alan yazından farklı çıkması hususunda araştırmanın sınırlılığı olarak şunu belirtmekte fayda vardır ki; çalışmada katılımcıların yaş dağılım oranlarının 1: 1 olmaması nedeniyle istatistiksel açıdan bu örnek çalışanların iş tatmin düzeyleri ve akıllı bağımlılık düzeylerinin demografik faktörler arasında yer alan yaş faktörüne göre farklılık gösterip göstermediği ile ilgili kesin bir yargıya varılarak genelleme gücünden yoksun olabilir. İlerleyen çalışmalarda eşit sayıda katılımcılardan elde edilen veriler ışığında söz konusu faktör ile ilgili genelleme yapmak daha doğru olacaktır.

Sonuç olarak çalışanların akıllı telefon bağımlılık düzeylerinin iş tatminleri üzerinde etkili olduğu, akıllı telefon bağımlılık düzeyleri yükseldikçe çalışanların iş tatmin düzeylerinin de artacağı, bunun sonucu olarak işlerinde daha verimli olacakları sonucuna ulaşılmıştır. Bu nedenle örgütlerin başarısı, verimliliği ve rakipleri arasında hayatta kalabilmesine yardımcı olan çalışanların iş tatmin düzeylerinin yüksek tutulması amacıyla yöneticilerin işyerlerinde çalışanlarının işlerini aksatmadıkları sürece iş tatmin düzeylerini artıran akıllı telefon kullanımlarına izin verilmesi yerinde olacaktır. Akıllı telefon bağımlılı̆̆ının olumsuz etkileri olduğu kaçınılmazdır fakat gelişen teknoloji ile bireylerin işleri ile ilgili birçok aşamada -e-mail takibi, iletişimi hızlı hale getirmesi, yer ve mekâna bağlı kalmaksızın görevleri yerine getirebilme gibi- kolaylıklar sağlayan, yoğun çalışma temposunda bireylerin az da olsa kendileri ile baş başa kalmalarına olanak tanıyan, sosyalleşme ihtiyaçlarına cevap verdiği için yoğun iş stresi ile mücadelelerinde onlara yardımcı olan bir araç olarak düşünüldüğünde çalışanların görev ve sorumluluklarını sekteye uğratmadığı ölçüde kullanımlarında olumlu katkılar sağlayacağı da göz ardı edilmemelidir.

Alan yazın incelendiğinde akıllı telefon bağımlılığı ile ilgili çalışmaların daha çok öğrenciler üzerinde gerçekleştirildiği görülmekte olup, çalışanlar üzerinde akıllı telefon bağımlılığı ile ilgili gerçekleştirilen bir çalışmaya rastlanılamamıştır. Bu bağlamda, çalışma kapsamında alan yazına önemli katkılar sağlayacak bulguların elde edilmiş olduğu söylenebilir.

Bu araştırma sadece çalışanların akıllı telefon bağımlılık düzeylerinin iş tatminleri üzerine etkisini belirlemek amacıyla gerçekleştirilmiştir. İleride yapılacak araştırmalarda, akıllı telefon bağımlılık düzeylerinin çalışanların performanslarına, motivasyonlarına, zaman yönetimlerine olan etkisi araştırılabilir. Ayrıca bu araştırmada iş kolu ayrımı gözetilmeksizin çalışanların akıllı telefon bağımlılık düzeylerinin iş tatminleri üzerine olan etkisi araştırılmış olup, ileride gerçekleştirilecek çalışmalarda belirli iş kolları üzerinde, özellikle dikkatin ve odaklanmanın şart olduğu iş kollarında, çalışanların akıllı telefon bağımlılık düzeylerinin iş tatminleri üzerine olan etkisinin yanı sıra, çalışanların iş sağlığı ve güvenliği üzerinde etkisinin de araştırılması gerçekleştirilebilir.

\section{KAYNAKÇA}

Agho, A. O., Mueller, C. W. ve Price, J. L. (1993). Determinants of employee job satisfaction: an, empirical test of a causal model, Human Relations, 46 (8), 1007-1027.

Alayvaz, C. ve Kesgin, B. (2020). Darülaceze başkanlığı çalışanlarının örgütsel bağlılık ve iş tatminleri üzerine bir araştırma, Girişimcilik ve Kalkınma Dergisi, 15 (2),1-14 .

Baykul, Y. ve Güzeller C. O. (2014).Sosyal Bilimler İçin İstatistik Spss Uygulamall, Ankara, Pegem Akademi.

Billieux, J., Van Der Linden, M. ve Rochat, L. (2008). The role of impulsivity in actual and problematic use of the mobile phone, Applied Cognitive Psychoogy, 22, 1195-1210.

Blanchard, A. L. , ve Henle, C. A. (2008). Correlates of different forms of cyberloafing: the role of norms and externallocus of control, Computers in Human Behavior, 24, 1067-1084.

Bragazzi, N. L. ve Puente, G. D. (2014). A proposal for including nomophobia in the new DSM-V, Psychology Research and Behavior Management, 7, 155-160. 


\section{M. Özdemir - Nurcan Çetiner 13/2 (2021) 1679-1694}

Büyüköztürk, Ş. (2002). Faktör analizi: temel kavramlar ve ölçek geliştirme kullanımı, Kuram ve Uygulamada Eğitim Yönetimi, 32, 470-483.

Büyüköztürk, Ş., Kılıç Çakmak, E., Akgün, Ö. E., Karadeniz, Ş. ve Demirel, F. (2014). Bilimsel Araştırma Yöntemleri, Ankara, Pegem Akademi.

Candan, H. ve İnce, M. (2016). Siber kaytarma ve örgütsel bağlllık arasındaki ilişkinin incelenmesine yönelik emniyet çalışanları üzerinde bir araştırma, Niğde Üniversitesi İktisadi ve İdari Bilimler Fakültesi Dergisi, 9(1), 229-235.

Chen, C., Zhang, K. Z. K., Gong, X., Zhao, S. J., Lee, M. K.O. ve Liang, L. (2017). Examining the effects of motives and gender differences on smartphone addiction, Computers in Human Behavior, 75, 891902.

Çalışkan, A. ve Hazır, K. (2012). Psikolojik güçlendirmenin iş tatminine etkisinde örgütsel bağlılığın aracılık rolü, Cag University Journal of Social Sciences, 9(2),48-76.

Çetiner, N. ve Atar, A. (2021). Sağlık Turizminde Lider-Üye Etkileşimi (Ed.), Sağllk Perspektifinden Örgütsel Psikoloji içinde (175-197. ss.), Konya, Eğitim Yayınevi.

Çetinkaya, F. Ö. ve Şahbaz, R. P. (2019). Sosyal medyada gelişmeleri kaçırma korkusunun kişinin tatil satın alma niyetine etkisi, Türk Turizm Araştırmaları Dergisi, 3(3), 383-402.

Çetinkaya, F. Ö. ve Şahbaz, R. P. (2020). Gelişmeleri kaçırma korkusunun kuşaklar üzerindeki tatil satın alma niyetlerine etkisi. Journal of Tourism and Gastronomy Studies, Special Issue (4), 152-167.

Dodd, N. G. ve Ganster, D. C. (1996). The interactive effects of variety, autonomy, and feedback on attitudes and performance, Journal of Organizational Behavior, 17, 329-347.

Eğinli, A. T. (2009). Çalışanlarda iş doyumu: kamu ve özel sektör çalışanlarının iş doyumuna yönelik bir araştırma, Atatürk Üniversitesi İktisadi ve İdari Bilimler Dergisi, 23(3), 35-52.

Eraslan, M., Karafil, A. Y., Akgül, M. H. ve Korkmaz, S. (2017). Üniversiteler arası spor müsabakalarına katılan muaythai sporcularının şiddet eğilimlerinin değerlendirilmesi, Mehmet Akif Ersoy Üniversitesi Sosyal Bilimler Enstitüsü Dergisi, 9 (22),404-412.

Eyel, C. Ş. ve Tutcu, A. (2020). İş doyumunun sanal kaytarma davranışı üzerindeki etkisi: Gaziantep ilinde özel sektörde çalışanlar üzerinde bir araştırma, İşletme Araştırmaları Dergisi, 12(4), 3596-3612.

George, D. Ve Mallery, P. (2010). SPSS for Windows Step by Step: A Simple Guide and Reference, 17.0 update (10a ed.) Boston, Pearson.

Göldağ, B. (2019). Akıllı telefon bağımlılığı ile algılanan stres ve yaşam doyumu arasındaki ilişkinin incelenmesi, Turkish Studies-Information Technologies and Applied Sciences, 14(2),193-212.

Henne, D. ve Locke, E. A. (1985). Job dissatisfaction: What are the consequences?", International Journal of Psychology, 20(2),221-240.

Işık, M. ve Kaptangil, İ. (2018). Akıllı telefon bağımlılığının sosyal medya kullanımı ve beş faktör kişilik özelliği ile ilişkisi: üniversite öğrencileri üzerinden bir araştırma, İnsan ve Toplum Bilimleri Araştırmaları Dergisi, 7 (2), 695-717.

Kavak, B., Kazancı Sunaoğlu, Ş. ve Taner, N. (2017). Yeniliği benimseyen kategorilerinin bütüncül ve analitik düşünme açısından farklılıkları: akıllı telefonlar için bir inceleme, Pazarlama ve Pazarlama Araştırmaları Dergisi, 20, 179-200.

Kemp, S. (2020a). Digital 2020, global digital over view, We are social Hootsuite, https://wearesocial.com/digital2020 (Erişim tarihi: 23 Aralık 2020).

Kemp, S. (2020). Digital 2020 October global statshot report, WearesocialHootsuite, https://wearesocial.com/blog/2020/10/social-media-users-pass-the-4-billionmark-as-global-adoption-soars (Erişim tarihi: 23 Aralık 2020). 


\section{M. Özdemir - Nurcan Çetiner 13/2 (2021) 1679-1694}

Kozan, H. İ. Ö., Kavaklı, M., Ak, M. ve Kesici, Ş. (2019). Akıllı telefon bağımlılığı, genel aidiyet ve mutluluk arasındaki ilişkilerin yapısal eşitlik modellemesi ile incelenmesi,Klinik Psikiyatri Dergisi, 22(4),21522159.

KwonMin, K. D., Cho, H. ve Yang, S. (2013). The smartphone addiction scale: development and validation of a short version for adolescents, PloSOne, 8(12), 1-7.

Lim, V. K. G. (2002). The IT way of loafing on the job: cyberloafing, neutralizing and organizational justice, Journal of Organizational Behavior, 23(5), 675-694.

Lim, V. K. G. ve Chen, D. J. Q. (2009). Cyberloafing at the workplace: gain or drain on work?, BehaviourE Information Technology, First published on: 11 November 2009 (iFirst), 1-11.

Lim, V. K.G. ve Chen, D. J.Q.(2012). Cyberloafing at the workplace: gain or drain on work?, Behaviour and Information Technology, 31 (4), 343-353.

Minaz, A. ve Bozkurt, Ö.Ç. (2017). Üniversite öğrencilerinin akıllı telefon bağımlılık düzeylerinin ve kullanım amaçlarının farklı değişkenler açısından incelenmesi, Mehmet Akif Ersoy Üniversitesi Sosyal Bilimler Enstitüsü Dergisi, 9 (21), 268-286.

Noyan, C. O., Darçın, A. E., Nurmedov, S., Yılmaz, O. ve Dilbaz, N. (2015). Akıllı telefon bağımlılığı ölçeğinin kısa formunun üniversite öğrencilerinde Türkçe geçerlilik ve güvenilirlik çalışması, Anadolu Psikiyatri Dergisi, 16 (Özel sayı.1), 73-81.

Oshagbemi, T. (2000). Gender differences in the job satisfaction of university teachers, Women in Management Review, 15(7),331-343.

Örücü, E., Yumuşak, S. ve Bozkır, Y. (2006). Kalite yönetimi çerçevesinde bankalarda çalışan personelin iş tatmini ve iş tatminini etkileyin faktörlerin incelenmesine yönelik bir araştırma, Yönetim ve Ekonomi, 13(1), 39-51.

Özaydın, M. M. ve Özdemir, Ö. (2014). Çalışanların bireysel özelliklerinin iş tatmini üzerindeki etkileri: bir kamu bankası örneği, İşletme Araştırmaları Dergisi, 6(1), 251-281.

Özler,D. E. ve Polat, G. (2012). Cyberloafing phenomenon in organizations: determinants and impacts, International Journal of eBusiness and eGovernment Studies, 4 (2), 1-15.

Öztürk, A. T. ve Aygün, İ. K. (2020). İş tatmini ve işgören performansı arasındaki ilişki üzerinde iş stresinin aracilık rolünün belirlenmesi, Gazi İktisat ve İşletme Dergisi, 6(3), 210-234.

Salam, Md A.(2017). Effects of psychological capital on job satisfaction and turnover intention: tha ihighered ucation perspective, Journal of Asia Pacific Studies, 4 (3), 203-218.

Samaha, M. ve Hawi, N. S. (2016). Relationships among smartphone addiction, stress, academic performance, and satisfaction with life, Computers in Human Behavior, 57, 321-325.

Saruhan, Ş. C. ve Özdemirci, A. (2016). Bilim, Felsefe ve Metodoloji, İstanbul, Beta Basım.

Sevimli, F. ve İşcan, Ö. F.(2005). Bireysel ve iş ortamına ait etkenler açısından iş doyumu, Ege Üniversitesi İ.I.B.F. Akademik Bakış Dergisi, 5 (1-2), 55-64.

Sığrı, Ü. ve Basım, N.(2006). İş görenlerin iş doyumu ile örgütsel bağlllık düzeylerinin analizi: kamu ve özel sektörde karşılaştırmalı bir araştırma, Selçuk Üniversitesi Sosyal ve Ekonomik Araştırmalar Dergisi, 6 (12), 131-154.

Sökmen, A. (2020). Etik liderliğin iş tatmini ve işten ayrılma niyetine etkisinde algılanan örgütsel desteğin aracı rolü: kamu sektöründe bir araştırma, İşletme Araştırmaları Dergisi, 12(4), 3467-3481.

Şen, C. ve Mert, İ. S.(2019). Psikolojik sermayenin iş tatmini, örgütsel bağlllık ve sinizm üzerindeki etkisi, Anemon Muş Alparslan Üniversitesi Sosyal Bilimler Dergisi, 7(4), 9-21.

Tabachnick, B. G. ve Fidell, L. S. (2013). Using Multivariate Statistics, Boston, Pearson.

Tekne, S. ve Güney, S. (2020). İş görenlerin bireysel özelliklerinin iş tatmini üzerindeki etkisi, Anadolu Bil Meslek Yüksekokulu Dergisi, 15 (58), 143-170. 
M. Özdemir - Nurcan Çetiner 13/2 (2021) 1679-1694

Tengilimoğlu, D. (2005). Hizmet işletmelerinde liderlik davranışları ile iş doyumu arasındaki ilişkinin belirlenmesine yönelik bir araştırma, Ticaret ve Turizm Eğitim Fakültesi Dergisi, 1, 23-45.

TÜIK, (2020). Hanehalkı Bilişim Teknolojileri (BT) Kullanımı Araştırması, https://data.tuik.gov.tr/Bulten/Index?p=Hanehalki-Bilisim-Teknolojileri-(BT)-KullanimArastirmasi-2020-33679 (Erişim Tarihi: 26 Aralık 2020).

Türk Dil Kurumu, (2020). https://sozluk.gov.tr/ (Erişim Tarihi: 16 Aralık 2020 ).

Ugrin, J. C.,J. Michael, P. Ve Marcus D., O. (2008). Cyber-slacking self-control, prior behavior and the impact of deterrence measures. Review of Business Information Systems, 12(1), 75-88.

Vitak, J., Crouse, J. ve La Rose, R. (2011). Personal internet use at work: understanding cyberslacking, Computers in Human Behavior, 27, 1751-1759.

Weiss, D. J., Dawis, R. V., England, G. W. ve Lofquist, L. H. (1967). Manual for the Minnesota satisfaction questionnaire, Minnesota Studies in Vocational Rehabilition, Minneapolis: University of Minnesota, Industrial Relations Center, 22, 1-119.

Yeşilay, (2020). Bağımlılık nedir? https://www. yesilay.org.tr/tr/ bagimlilik/ bagimlilik-nedir (Erişim tarihi: 16 Aralik 2020).

Yeşilay, (2020a). Teknoloji bağımlılığı, https://www. yesilay.org.tr/tr/ bagimlilik/ teknoloji-bagimliligi(Erişim Tarihi: 15 Aralık 2020).

Yıldırım, S., Ergüzel, T. T. ve Sayar, G. H. (2019). Akıllı telefon bağımlılığı, Current Addiction Research, 3(1), 25-30. 